\title{
David Shambaugh (ed.), Charting China's Future: Domestic and International Challenges
}

London and New York, Routledge, 2011, 187 pp.

Ding Hui

\section{OpenEdition}

\section{Journals}

Electronic version

URL: http://journals.openedition.org/chinaperspectives/6291

DOI: 10.4000/chinaperspectives.6291

ISSN: 1996-4617

\section{Publisher}

Centre d'étude français sur la Chine contemporaine

Printed version

Date of publication: 1 September 2013

Number of pages: 92-93

ISSN: 2070-3449

\section{Electronic reference}

Ding Hui, « David Shambaugh (ed.), Charting China's Future: Domestic and International Challenges », China Perspectives [Online], 2013/3 | 2013, Online since 01 September 2013, connection on 24

September 2020. URL : http://journals.openedition.org/chinaperspectives/6291 ; DOI : https://doi.org/ 10.4000/chinaperspectives.6291 


\section{Book reviews}

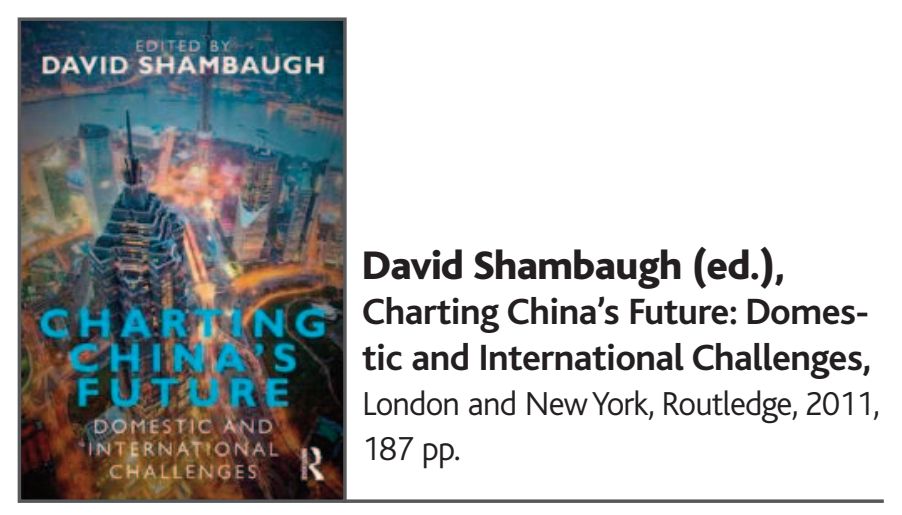

DING HUI

$\mathrm{P}$ rognostications made by political scientists easily fall into the abyss of facile speculation, because real-life politics change constantly and may give rise to unexpected outcomes. Ambitious theoretical generalisations based on limited observational data can be proved false by new data that do not support the existing theses. In this sense, there is nothing more difficult than to foresee the future of a political regime as full of complexities as China's. Contemporary China has its own intrinsic dynamics that cannot be perfectly explained through any established analytical model developed in the Western academic context. However, China experts, especially quite a few American Sinologists, have never stopped making bold, insightful prognoses over the wrenching and systematic changes in China over the years. Unfortunately, China's development since 1989 once again betrayed their wishful speculations; neither radical democratisation nor sudden collapse of the regime occurred. On the contrary, the Chinese Communist Party (CCP) maintains a steadily grip on state power and keeps society under its effective control. Most importantly, China has become the world's second largest economy on the way to its "peaceful rise." Why is there such a big discrepancy between scholarly predictions and the real China? Is it worth writing yet another book vainly attempting to chart China's future?

This book edited by David Shambaugh, one of the leading political scientists studying China, seeks to fulfil this "mission impossible" through a whole new approach. The contributors to this volume do not aim at making general, long-term predictions. Rather, as Shambaugh clearly states, they seek to figure out the near- and mid-term development of China up until 2015 (p. 174). They first provide comprehensive, nuanced portraits of current China with regard to domestic issues such as politics, the economy, and society as well as international issues at the global and regional level. Based on these informative descriptions of the status quo, the contributors then sketch out various possible scenarios of China's developmental trajectory in the respective spheres they observe. Intentionally, they do not share a common theoretical model, nor do they adopt a comparative empirical perspective. Rather, what they claim to accomplish is to apply a thin layer of analysis to in-depth information that focuses on today's China and is "free of social-science jargon and extensive footnotes" (p. 2).
Yet, rejecting a homogenous theoretical model does not mean there is no consensus among Shambaugh and his contributors. Rather, they seek to understand China from a historical-sociological institutionalist perspective. China is seen as a unique institution capable of being self-sustaining and self-adapting and which therefore has managed to keep its "dynamic stability" (p. 174). On the one hand, following the logic of path dependence, none of the authors predicts dramatic change in the short run. Instead, they insist that the status quo will generally persist. On the other hand, they identify various challenges confronting the Chinese state and society, both internally and externally. Whether these challenges will develop into more threatening scenarios and how they will be dealt with seems vital to the future stability of China and its long-term development.

According to the authors, among all spheres within China, the political sphere is the most robust against radical reform. Brødsgaard argues that the future of the Chinese political system will be neither a linear process toward democracy nor a dramatic regime collapse, but rather a "resilient authoritarianism" dominated by the CCP with an amazing ability to learn and adapt (p. 20). In Shambaugh's words, political issues in China will not become an independent variable and driving force that pushes forward change in other spheres (p. 176).

Similarly, the development of the social sphere remains quite circumscribed as well. In their respective chapters, Murphy draws our attention to the expansion of "public space" through new media and Potter discusses recent and potential reforms in various legal sectors. However, both authors have come to the same conclusion that the party-state still claims its powerful domination and control over the gradual and limited expansion of civil society.

In contrast with the political and social spheres, the economic domain is exposed to external influences and suffers from internal vulnerabilities. Nolan indicates that China will continue to be successful in weathering the storm of global financial crisis in the short term. However, since the Chinese economy has been deeply integrated into the global economy system, it will not be immune to external shocks. It will take a long time to "rebalance" China's development path from the export-oriented model dependent on high-income countries to a growth model more driven by domestic consumption. In the mid-term, the uncertainty of the performance of Western countries in the still on-going financial crisis can impact China's own growth, trade, and outbound investment (pp. 52-53). In addition, there are some serious vulnerabilities in China's micro-economy, such as high inflation and rising real estate prices, which are ticking time bombs that could go off at any time.

With regard to China's future at the international level, the authors consider economic growth a stabilising factor that could facilitate the status quo, while the "rise" of China might be a destabilising factor that could give rise to conflicts and challenges out of its own control. First, continuing economic growth indicates that a stronger Chinese economy will tend to improve or stabilise its ties with the great powers, the developing world, and China's Asian neighbours. Particularly, the growing economic integration 
between mainland China and Taiwan, Hong Kong, and Macau might facilitate the normalisation process toward the peaceful resolution of the crossstraits issue, and strengthen confidence over "one country, two systems" in the two Special Administration Regions. Secondly, China will encounter severe challenges to its strategic transition from "keeping a low international profile" (taoguang yanghui) to "rising peacefully" (heping jueqi). On the one hand, there are increasing protests against China's export dumping, natural resource exploitation, and expatriate labour both in developed and developing countries. On the other hand, there is growing criticism of its indifference to issues of good governance such as corruption and human rights and to issues of responsible involvement as a great power in promoting global security.

In sum, this volume is a clearly written, well-informed, and forward-looking book that helps understand the complexities and challenges of China's development. Two years after the publication of this reasoned work, the sober prognoses made by Shambaugh and his contributors have generally proved quite tenable and convincing. The historic leadership succession at the $18^{\text {th }}$ National Party Congress did not bring abrupt systemic change. And the ongoing Euro crisis has proved to be not an unbearable external economic shock, but rather a chance for China to claim leadership in resolving the international economic crisis without simply following Western prescriptions. It is reasonable to agree with the authors' prognostication that in the next few years, China will handle those domestic and international challenges relatively well.

I Ding Hui is an independent researcher who in 2012 obtained his PhD from Universität Heidelberg, Institut für Politische Wissenschaft, Germany (dingdanghui@hotmail.com).

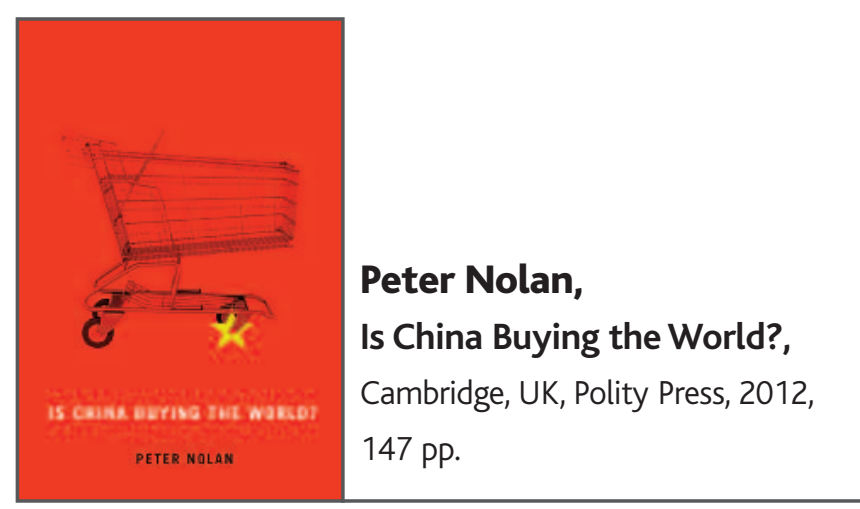

\section{YU TAO}

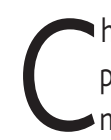
hina's remarkable economic performance since the late 1970s is impressive in many ways. The constant high growth rate lasting for more than three decades is in itself a miracle. The hugely successful development of the world's most populous country is an incredible achievement, especially considering that prior to this accomplishment China had suffered repeated foreign invasions and domestic turbulence for more than a century. The communist regime's survival and prosperity in China after the end of the Cold War also challenges the prediction many scholars made soon after the fall of the Berlin Wall and the collapse of the Soviet Union.

Contrary to the once popular claim that China would soon follow the example of the disbanded Soviet Union and its European satellite states, the
"Oriental Giant Dragon" has now emerged as one of the world's most influential countries. China is the second largest economy in the world, and its significant role in the international arena has become increasingly obvious. Under these circumstances, it is unsurprising that many scholars, politicians, and business elites have become captivated by China's dramatic rise in the last three-and-a-half decades. Mainstream economists and China specialists in academia are heatedly debating whether the country's growth is stable and sustainable. Meanwhile, to a considerable number of political and business leaders in developed countries, the rapid rise of a state led by a communist party presents an urgent threat that, if not tackled, will soon destabilise the established economic and political order of the international community.

Such a myth is taken on and cleared up by Peter Nolan, the Sinyi Professor of Chinese Management at the University of Cambridge and one of the world's most prominent experts on China's economy, in his new volume Is China Buying the World?.Through answering the fascinating question raised by its title, this book convinces its readers that a richer and stronger China is not buying the world. Contrary to the conventional wisdom that accuses China of taking over companies in the developed world through acquisitions and/or investments, Nolan's comparison of the scales and strategies of large Chinese and Western firms in several key industries, including manufacturing and finance, suggests that China's economic influence is relatively weak outside its soil, and he further argues that China's economic expansion faces a series of tough obstacles. Therefore, according to Nolan, "China has not yet bought the world and shows little sign of doing so in the near future" (p. 143).

Nolan's new volume clearly targets a wide audience. Yet, as a serious academic book, it is based on the author's original research into empirical data collected from big firms. After a compelling introduction highlighting the significance of China's rise and some related concerns and debates, this book consists of four chapters and a conclusion. The brief first chapter raises two key questions that run through the entire volume: who are "we" (by which Nolan refers to high-income countries) and who are "they" (by which Nolan means the developing world with China at the forefront). The definitions of and boundary between "we" and "they" used to be clear and explicit. As Nolan shows in the second and third chapters, however, this situation has been fundamentally changed by the deepening capitalist globalisation.

According to Nolan, around the time that China shifted from political campaigns to economic development, the world economy "entered a new phase of capitalist globalisation" (p. 15). As shown by some detailed and explicated figures that Nolan calculates through data from several leading manufactures in the automobile and beverage industries, this new wave of globalisation, driven by the liberalisation of trade and capital flows, has enabled many large firms to accelerate their international expansion, either through intense merger and acquisition activities or by organic growth. During this process, while keeping their headquarters in high-income countries, many large firms have experienced massive asset restructuring in the global market-place. Thanks to the globalisation process and their supreme advantages in technology, capital, human resources, and market experiences, these large firms are able to upgrade their asset portfolios by selling off "non-core businesses" and concentrating on "core businesses." The emergence of industrial concentration has thus spread throughout all high-income countries and into large parts of the developing world. As a result, according to Nolan, wealth, technology, and business power have become significantly concentrated among a few huge firms in developed countries, but the growth 